\title{
Air particulate matter SRM 1648a primes macrophages to hyperinflammatory response after LPS stimulation
}

\author{
Anna Gawda ${ }^{1}$ - Grzegorz Majka ${ }^{1} \cdot$ Bernadeta Nowak $^{1} \cdot$ Małgorzata Śróttek $^{1} \cdot$ Maria Walczewska $^{1}$. \\ Janusz Marcinkiewicz ${ }^{1}$ (i)
}

Received: 2 February 2018 / Revised: 14 May 2018 / Accepted: 15 June 2018 / Published online: 19 June 2018

(c) The Author(s) 2018

\begin{abstract}
Objective Exposure to air particulate matter (PM) is associated with chronic inflammatory and autoimmune diseases. Macrophages are responsible for the regulation of chronic inflammation. However, whether PM affects macrophage polarization remains unclear. The aim of this study was to evaluate whether nontoxic concentrations of urban PM are able to prime macrophages to altered inflammatory response upon LPS challenge.

Methods We used two forms of the urban particulate matter SRM 1648a, intact PM and PM deprived of organic compounds $(\mathrm{PM} \Delta \mathrm{C})$. Peritoneal murine macrophages were exposed to different concentrations of PM for $24 \mathrm{~h}$ and then challenged with LPS. Production of inflammatory mediators by macrophages was measured to test immunostimulatory/priming capacity of PM.

Results Particulate matter used at non-cytotoxic concentrations induced a dose-dependent production of proinflammatory cytokines (TNF- $\alpha$, IL-6, IL-12p40). By contrast, PM $\Delta$ C were not able to stimulate macrophages. However, macrophages primed with both forms of PM show proinflammatory response upon LPS challenge.

Conclusions Our data indicate that exposure of macrophages to low concentrations of PM may prime the cells to hyperinflammatory response upon contact with LPS. Further studies are necessary to explain whether the exposure of patients suffering from chronic inflammatory diseases to particulate matter is responsible for the exacerbation of clinical symptoms during bacterial infections.
\end{abstract}

Keywords Air pollution $\cdot$ SRM $1648 \mathrm{a} \cdot$ Particulate matter $\cdot$ Inflammation $\cdot$ Macrophage priming

\section{Introduction}

The last decade has significantly changed the perception of etiopathogenesis of inflammatory and autoimmune disorders (AIDs) such as asthma, chronic obstructive pulmonary disease, rheumatoid arthritis and atherosclerosis [1,2]. There is substantial evidence proving that chronic inflammation plays a major role in the development and progression of these disorders. Inflammatory response driven by the breakdown of immune tolerance and malfunctioning of the immune system

Responsible Editor: John Di Battista.

Janusz Marcinkiewicz

mmmarcin@cyf-kr.edu.pl

1 Chair of Immunology, Jagiellonian University Medical College, Kraków, Poland were deemed to constitute a common background for the above-mentioned diseases [3].

Development of these chronic civilization diseases is triggered by a set of factors, both genetic and environmental [4]. Among environmental factors, such as exposure to tobacco smoke, infectious agents, radiation and ultraviolet light exposure, air pollution seems to be specifically involved in the pathogenesis of AIDs [5]. Air pollutants include gases (carbon monoxide, nitrates, sulfur dioxide and ozone), aerosols, as well as particulate matter (PM) that may interact at multiphase interfaces. Primarily, the increased concentration of pollutants in the air has been strongly associated with lung inflammatory diseases [6].

While the coincidence of air pollution and AIDS occurrence has been reported several times, the mechanism behind this relationship is still not clear [7]. Local impact of the inhaled particles seems obvious enough, but how can PM affect other tissues and initiate or aggravate the autoimmune 
process? Some hypotheses hold the chronic inflammatory process responsible for the pathogenesis of these disorders [8]. Induction of oxidative and nitrosative stress by the inhaled inorganic particles (such as metal oxides) might fuel the chronic inflammation in the lung, cause tissue injury and lead to the generation of oxidatively modified autoantigens. Importantly, it has been documented that alveolar macrophages, the first line of defense of the respiratory tract, engulf PM and secrete a wide array of inflammatory mediators [9].

In general, macrophages, major phagocytes of the immune system, are key cells involved in the regulation of chronic inflammation accompanying numerous infectious and autoimmune diseases [10]. Macrophages, depending on the properties of the stimulant used, may be polarized into distinct functional phenotypes: M1-type proinflammatory/ microbicidal cells, M2-type anti-inflammatory/suppressor cells or may acquire a mixed state of activation [11, 12]. Recently, conflicting data have been reported concerning the effects of airborne particulate matter on macrophage activation and polarization [13-15]. All these data explain why we have chosen macrophages as the experimental model cells to be used in vitro to test the influence of PM on innate immunity and inflammatory response $[16,17]$.

The main aim of this study was to evaluate whether low, nontoxic concentrations of urban PM are able to prime macrophages to altered inflammatory response upon LPS challenge. To fulfill this task, we endeavored to elucidate whether standard urban SRM 1648a samples (PM) and $\mathrm{PM} \triangle \mathrm{C}$, the PM-derived samples significantly devoid of organic content, might affect the viability and secretory functions of the peritoneal murine macrophages. Both direct and priming effects of PM on macrophages were studied. To evaluate the impact of low, non-stimulatory concentrations of PM on the inflammatory response of macrophages, PMprimed cells were challenged with LPS, a potent M1-type, proinflammatory stimulus and a major pathogenic factor of Gram-negative bacterial infections [18].

\section{Materials and methods}

\section{PM samples}

Urban particulate matter samples SRM 1648a (encoded as PM) were purchased from National Institute of Standards and Technology in the United States of America and used as the reference material. The samples were composed of particulate matter collected over a period of 1 year (1976-1977) in the St. Louis (MO) area into a specially designed baghouse. The reference material consists of highest level of iron $(\mathrm{Fe})$ and zinc $(\mathrm{Zn})$ among transition metals [19]. SRM 1648a is a conglomeration of fine and ultrafine particles with the mean particle diameter $5.85 \mu \mathrm{m}$. PM contains inorganic elements such as: chlorine $(\mathrm{Cl})$, potassium $(\mathrm{K})$, calcium $(\mathrm{Ca})$, titanium $(\mathrm{Ti})$, vanadium $(\mathrm{V})$ chromium $(\mathrm{Cr})$, manganese $(\mathrm{Mn}), \mathrm{Fe}$, nickel $(\mathrm{Ni})$, copper $(\mathrm{Cu}), \mathrm{Zn}$, bromine $(\mathrm{Br})$, rubidium $(\mathrm{Rb})$, strontium $(\mathrm{Sr})$ and lead $(\mathrm{Pb})$ (Certificate of analysis Standard Reference Material 1648a Urban Particulate Matter). Moreover, the SRM 1648a contains ca. 13\% of carbon, including $10.5 \%$ of organic carbon [19]. Plasma Zepto system (Diener electronic $\mathrm{GmbH}+\mathrm{Co} . \mathrm{KG}$ ) has been used in our studies to eliminate organic compounds present in the reference material. Samples were treated with low-temperature plasma at highest power for $120 \mathrm{~min}$. Content of carbon was determined by the elementary analysis and total organic carbon analyzer (Schimadzu, TOC-V series). The decreased carbon content from $14 \%$ in original samples (PM) to 2\% in the plasma-treated PM samples (encoded as $\mathrm{PM} \Delta \mathrm{C}$ ) has been observed (Mikrut, manuscript in preparation).

Before use, $\mathrm{PM}$ and $\mathrm{PM} \Delta \mathrm{C}$ particles were weighted on a high precision microbalance and a stock suspension of $2 \mathrm{mg} / \mathrm{ml}$ in DPBS (Dulbecco's phosphate-buffered saline) was prepared. The samples were sonicated for $20 \mathrm{~min}$ before use in each experiment.

\section{Mice}

Inbred C57BL/6 male mice (8-12 weeks of age, 18-22 g) were maintained in the Animal Breeding Unit No 2, Faculty of Medicine, Jagiellonian University Medical College, Kraków. All mice were housed in the laboratory room with water and standard diet ad libitum. The authors were granted permission (KRA1_16_2016) by the Local Ethics Committee to use mice in this study.

\section{Cells: preparation of macrophages}

Peritoneal macrophages were induced by an intraperitoneal injection (i.p.) of 3\% thioglycollate (1.5 $\mathrm{ml}$ per mouse) (Sigma-Aldrich). Macrophages were collected $96 \mathrm{~h}$ later by washing out the peritoneal cavity with DPBS. The cells were centrifuged $(1500 \times g, 10 \mathrm{~min})$, and red blood cells were lysed by osmotic shock using lysing buffer $(155 \mathrm{mM}$ $\mathrm{NH}_{4} \mathrm{Cl}, 10 \mathrm{mM} \mathrm{NaHCO} 3,0.1 \mathrm{mM}$ EDTA). At least three mice were used as donors of peritoneal macrophages for each experiment.

\section{Cell culture and the experimental model}

Macrophages were seeded into 24-well flat-bottom cell culture plates (BD) at a density of $5 \times 10^{5} /$ well in IMDM (Iscove's Modified Dulbecco's Medium) with $25 \mathrm{mM}$ HEPES, supplemented with $5 \%$ fetal calf serum (FCS), $2 \mathrm{mM}$ L-glutamine (Cytogen) and $0.04 \mathrm{mg} / \mathrm{ml}$ gentamycin 
(KRKA). After $2 \mathrm{~h}\left(\mathrm{CO}_{2}\right.$ incubator, $\left.37{ }^{\circ} \mathrm{C}\right)$, the culture medium containing non-adherent cells and extracellular products of the seeded cells was removed and replaced by the fresh IMDM. Then, the remaining adherent cells (peritoneal macrophages) were used to study the immunostimulatory properties of PM samples in two experimental models. Experiments were repeated at least three times.

A. Direct immunostimulatory effect of PM Peritoneal macrophages were incubated with original (PM) or plasmatreated $(\mathrm{PM} \Delta \mathrm{C})$ samples at concentrations ranging from 1 to $400 \mu \mathrm{g} / \mathrm{ml}$ for $24 \mathrm{~h}$. After that time, supernatants were collected and frozen at $80{ }^{\circ} \mathrm{C}$ until further use.

B. Priming effect of $P M$ Peritoneal macrophages were pre-treated with $\mathrm{PM}$ or $\mathrm{PM} \Delta \mathrm{C}$ (at concentrations ranging from 1 to $400 \mu \mathrm{g} / \mathrm{ml}$ ) for $24 \mathrm{~h}$. After that time, the medium was collected and replaced with the fresh one containing LPS $(100 \mathrm{ng} / \mathrm{ml}) .24 \mathrm{~h}$ later $(24-48 \mathrm{~h}$ of the experiment), supernatants were collected and frozen at $80{ }^{\circ} \mathrm{C}$ until further analyses. Cells were studied in a Western blot and flow cytometry analysis.

\section{Evaluation of cell morphology}

Thioglycollate-induced peritoneal macrophages were cultured as described above. After $24 \mathrm{~h}$ culture, with or without $\mathrm{PM} / \mathrm{PM} \Delta \mathrm{C}$, cells were examined under light microscopy using Axiovert 40CLF inverted microscope (Carl Zeiss). Cells cultured in UpCell 24 Multidish plates (Nunc) were transferred from $\mathrm{CO}_{2}$ incubator $\left(37^{\circ} \mathrm{C}\right)$ and kept for $30 \mathrm{~min}$ at a room temperature, to allow the detachment of the adherent cells. Then, cells were washed in PBS containing $2 \%$ FCS and $0.02 \%$ sodium azide and analyzed on Becton Dickinson FACS Calibur with CellQuest Pro Software (BD Biosciences). Cell morphology was measured on FSC/SSC plots after excluding cell debris (gate R1) and then gating on FSC high macrophages (gate R3) and low FSC events (damaged, dying cells) (gate R2).

\section{Determination of cytokines concentration}

Cytokine levels in cell culture supernatants were measured by sandwich ELISA. Microtiter plates (Costar EIA/RIA plates, Corning Inc.) were coated with a cytokine-specific antibody. Expression levels of IL-6, IL-10, and IL-12p40 were measured according to the manufacturer's instructions (OptEIA Sets, BD Biosciences). TNF- $\alpha$ level was measured according to the manufacturer's instructions (ELISA ReadySet-Go, eBioscience). In all cases, $10 \%$ FCS in PBS was used as a blocking solution. TMB substrate solution (BioLegend) was used to develop a colorimetric reaction, which was stopped with $2 \mathrm{M}$ sulfuric acid. Optical density was measured at $450(570) \mathrm{nm}$ using a microtiter plate reader (PowerWaveX, Bio-Tek Instruments).

\section{Nitrite $\left(\mathrm{NO}_{2}{ }^{-}\right)$determination}

The level of nitrites (an oxidative end product of NO) was determined by a microplate Griess assay [20]. Briefly, $100 \mu \mathrm{l}$ of cell supernatants was incubated with an equal volume of Griess reagent [1\% sulphanilamide in $2 \mathrm{M} \mathrm{HCl}$ (SigmaAldrich) and $0.1 \% \mathrm{~N}$-1-naphthylenediamine dihydrochloride in deionized water $(\mathrm{POCH})]$ at room temperature (RT) for $10 \mathrm{~min}$. The absorbance at $550 \mathrm{~nm}$ was measured by a microplate reader. Nitrite concentration was calculated from a sodium nitrite standard curve.

\section{$\mathrm{PGE}_{2}$ determination}

$\mathrm{PGE}_{2}$ concentration in supernatants was determined by Prostaglandin $\mathrm{E}_{2}$ Monoclonal EIA kit (Cayman Chemical) according to the manufacturer's instruction.

\section{Western blot analysis}

Expression levels of COX-2, iNOS, and HO-1 proteins in cell cytosol were determined by Western blot assay in macrophages after PM/PM $\Delta \mathrm{C}(24 \mathrm{~h})$ and LPS ( $24 \mathrm{~h})$ treatment. Upon supernatant collection, cells were lysed in lysis buffer (1\% Triton X-100, 0.1\% SDS in PBS) containing protease inhibitor cocktail (Sigma-Aldrich). Protein concentrations in lysates were determined using a bicinchoninic acid protein assay kit (Sigma-Aldrich). Samples containing equal amounts of total protein were mixed with gel loading buffer (0.125M Tris, $4 \%$ SDS, 20\% glycerol, 0.2M dithiothreitol, $0.02 \%$ bromophenol blue) at a $2: 1$ ratio (v/v) and boiled for $4 \mathrm{~min}$. Samples of $20 \mu \mathrm{g}$ or $10 \mu \mathrm{g}$ of total protein per lane were separated on 10\% SDS-polyacrylamide gels (Biosciences) using the Laemmli buffer system. Proteins were transferred to nitrocellulose membranes (Bio-Rad). Nonspecific binding sites were blocked overnight at $4{ }^{\circ} \mathrm{C}$ with $4 \%$ non-fat dried milk. Membranes were incubated for $2 \mathrm{~h}$, at a RT with polyclonal antibodies to COX-2 (Cayman), monoclonal antibody to HO-1 1:1000, (Enzo), or iNOS 1:1000, (Enzo). Bands were detected with alkaline phosphataseconjugated secondary goat antibody to the rabbit $\operatorname{IgG}$ whole molecule (1 h at RT, 1:3000), (Sigma-Aldrich) and developed with BCIP/NBT alkaline phosphatase substrate (Sigma-Aldrich). Membranes were re-probed with monoclonal anti $\beta$-actin antibody (clone AC-15, $1 \mathrm{~h}$ at RT, 1:3000, Sigma-Aldrich). Prestained SDS-PAGE standards (low and high range) (Bio-Rad) were used for molecular weight determinations. Protein bands were scanned and analyzed with the Scion Image freeware (Scion Corp.). Data were normalized to the constitutive expression level of $\beta$-actin protein. 


\section{Statistical analysis}

Statistical significance of differences between groups was analyzed using one-way ANOVA, followed, if significant, by a Dunnett's test for post hoc comparison. Results are expressed as mean \pm SEM values. A $P$ value $<0.05$ was considered statistically significant. Analysis was performed using Graphpad Prism v. 5.01 (GraphPad Software, Inc.).

\section{Results}

\section{The effect of PM and PMAC on cell morphology and viability}

Morphological features of cells exposed in vitro to PM or $\mathrm{PM} \Delta \mathrm{C}$ were examined by light microscopy (Fig. 1) and flow cytometry (Fig. 2). To evaluate direct influence of PM and $\mathrm{PM} \Delta \mathrm{C}$ on peritoneal macrophages, cells were cultured in the presence of various concentrations $(1-400 \mu \mathrm{g} / \mathrm{ml})$ of the PM/PM $\Delta \mathrm{C}$ for $24 \mathrm{~h}$. Corpuscular nature of the tested
Fig. 1 Microscopic images (inverted microscope, $\times 20$ magnification) of macrophages cultured in vitro with PM or $\mathrm{PM} \Delta \mathrm{C}$. Mouse peritoneal macrophages were cultured in vitro for $24 \mathrm{~h}$ in the presence of PM at concentrations of $30 \mu \mathrm{g} / \mathrm{ml}$ (b), $100 \mu \mathrm{g} / \mathrm{ml}$ (d), $400 \mu \mathrm{g} / \mathrm{ml}$ (f) or PM $\Delta \mathrm{C}$ at concentrations of $30 \mu \mathrm{g} / \mathrm{ml}$ (c), $100 \mu \mathrm{g} / \mathrm{ml}$ (e), $400 \mu \mathrm{g} / \mathrm{ml}(\mathrm{g})$ or in medium only (a-control, untreated cells). The images are representative pictures of cell cultured in at least three independent experiments run in three experimental replicates

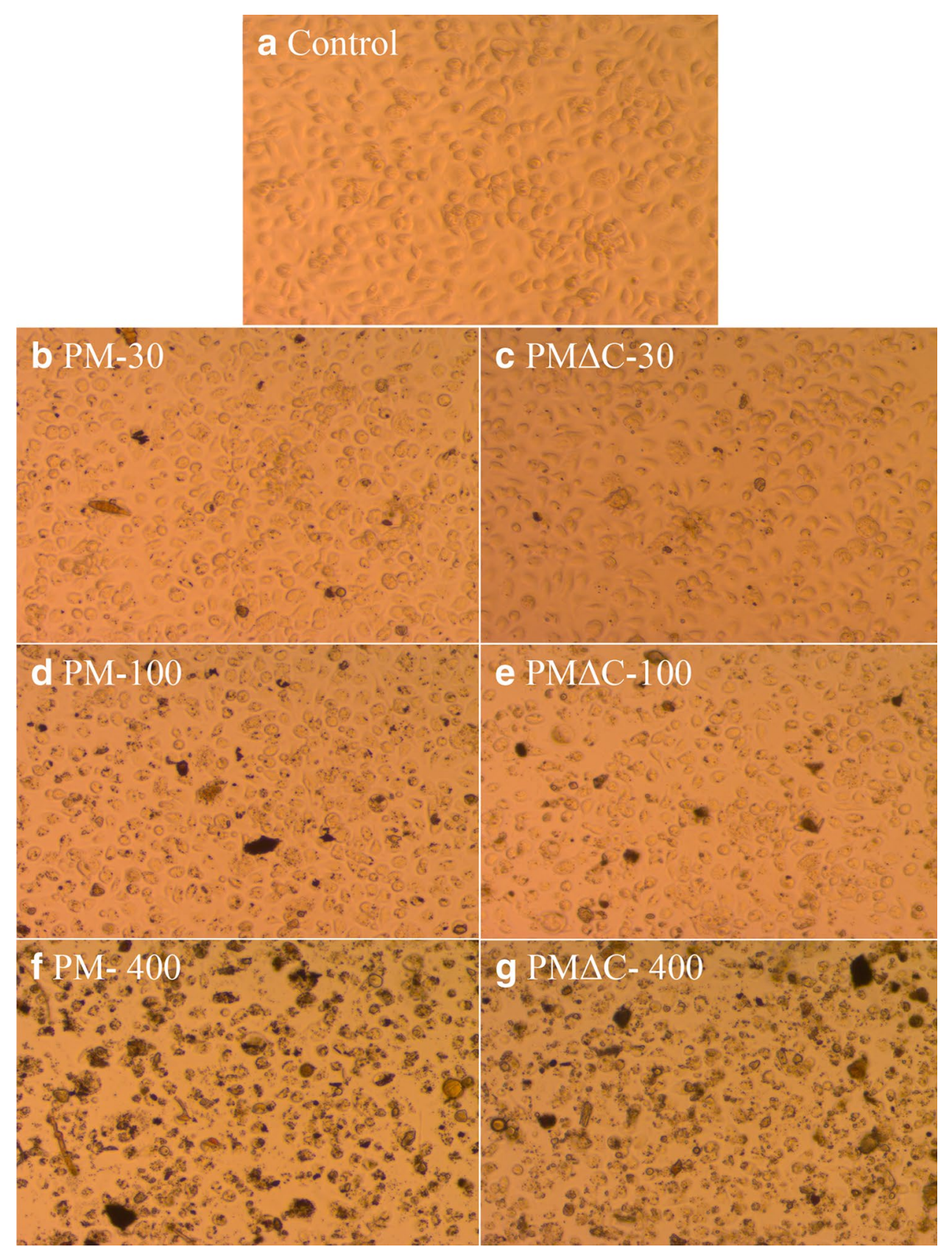


Fig. 2 Morphological changes in peritoneal exudate cells cultured in vitro in the presence of $\mathrm{PM}$ or $\mathrm{PM} \Delta \mathrm{C}$ shown as dot plot images of the cell size (FSC) vs internal complexity (SSC). Cells were cultured in vitro for $24 \mathrm{~h}$ in the presence of PM (middle panel) at concentrations of $30 \mu \mathrm{g} / \mathrm{ml}(\mathbf{b}), 100 \mu \mathrm{g} /$ $\mathrm{ml}(\mathbf{d}), 400 \mu \mathrm{g} / \mathrm{ml}$ (f) or PM $\Delta \mathrm{C}$ (lower panel) at concentrations of $30 \mu \mathrm{g} / \mathrm{ml}(\mathbf{c}), 100 \mu \mathrm{g} / \mathrm{ml}(\mathbf{e})$, $400 \mu \mathrm{g} / \mathrm{ml}(\mathrm{g})$. Negative control cells were cultured in medium only (a). Cells within gate R1 were analyzed $(\mathrm{R} 1=100 \%)$. Percentage of small (low FCS) cells (gate R2) and big (high FCS, normal for macrophages) (gate R3) are shown. The data was obtained from three independent experiments run in three technical replicates

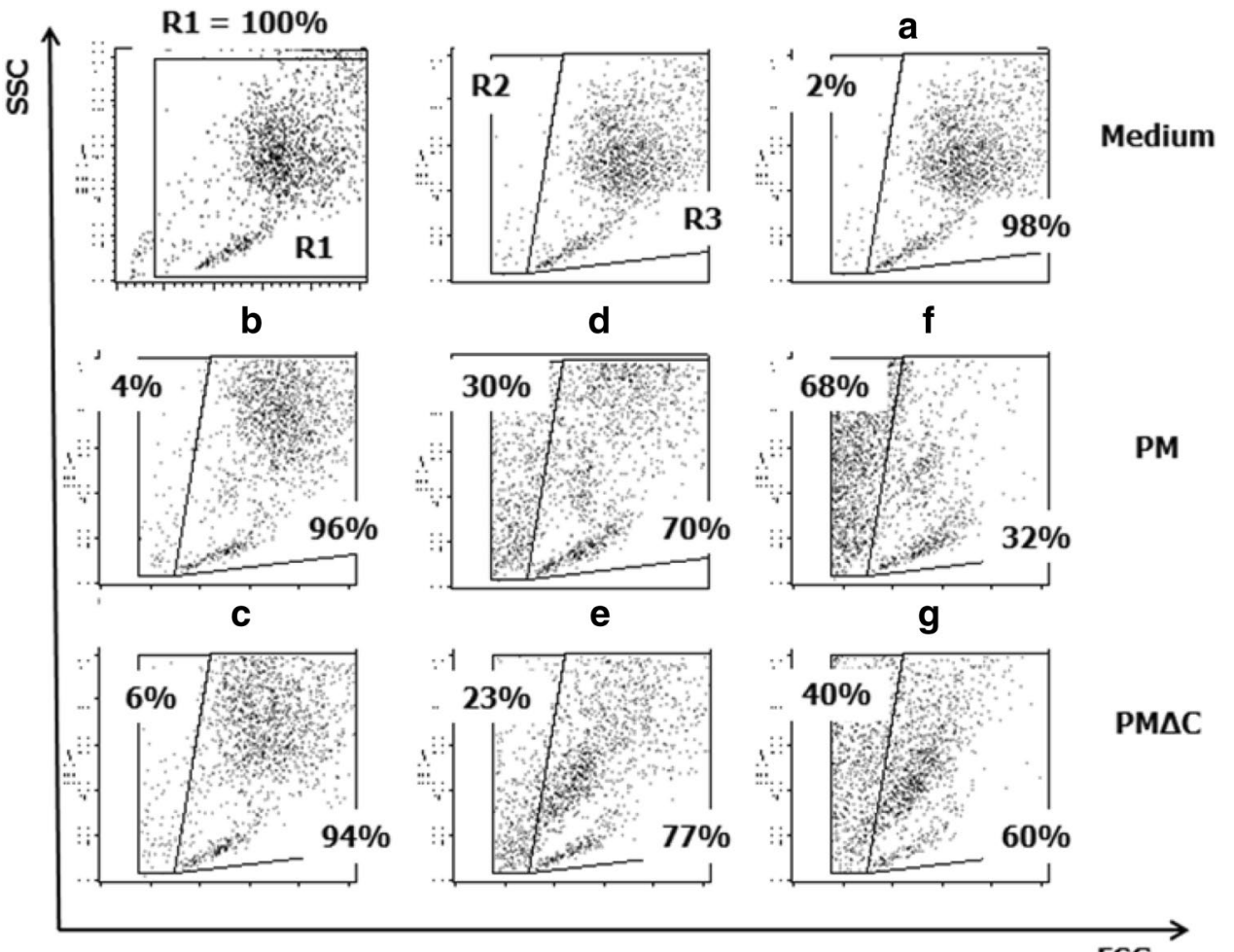

FSC

\begin{tabular}{|l|l|l|l|l|l|}
\hline SSC Mean [R3] & $a-553$ & $b-670$ & $c-636$ & $d-580$ & e - 536 \\
\hline
\end{tabular}

samples causes that only a fraction of the cells in culture is in direct contact with $\mathrm{PM} / \mathrm{PM} \Delta \mathrm{C}$ used at low concentrations $<100 \mu \mathrm{g} / \mathrm{ml}\left(<60 \mu \mathrm{g} / \mathrm{cm}^{2}\right)$. However, some differences between microscope images of $\mathrm{PM}$ and $\mathrm{PM} \Delta \mathrm{C}$ can be observed. As shown in Fig. 1b-e, PM at concentrations of 30 and $100 \mu \mathrm{g} / \mathrm{ml}$ was accumulated by a larger numbers of macrophages than $\operatorname{PM} \Delta \mathrm{C}$ used at the same concentrations. It indicates that PM samples are engulfed more readily than $\mathrm{PM} \Delta \mathrm{C}$ ones.

This phenomenon was confirmed using flow cytometry (Fig. 2). Analysis of cell size (FSC) vs cell granularity (SSC) revealed that in the presence of $\mathrm{PM}$ or $\mathrm{PM} \Delta \mathrm{C}$ at a concentration of $30 \mu \mathrm{g} / \mathrm{ml}$ the SSC parameter has increased (Fig. 2b, c) compared to control untreated cells (Fig. 2a). SSC Mean values have risen from 553 (Fig. 2a, control) to 670 (PM $30 \mu \mathrm{g} / \mathrm{ml}$, Fig. 2b) and 636 (PM $\Delta$ C $30 \mu \mathrm{g} / \mathrm{ml}$, Fig. 2c). The difference between PM (SSC mean value $=580)$ and $\mathrm{PM} \Delta \mathrm{C}(\mathrm{SSC}$ mean value $=536)$ is more pronounced at a concentration of $100 \mu \mathrm{g} / \mathrm{ml}$ (Fig. 2d, e). These data suggest that engulfment of PM $\Delta \mathrm{Cs}$ is less effective compared to PM. High concentrations of tested samples (above $100 \mu \mathrm{g}$ / $\mathrm{ml}$ ) had detrimental impact on cells in the culture. PM at $400 \mu \mathrm{g} / \mathrm{ml}$ caused cell injury, as a large amount of debris is visible (Fig. 1f). Damage of the cells is depicted in flow cytometry dot plots (Fig. 2f, g). The percentage of cells in gate R3 decreased from 98\% (control, Fig. 2a) to $32 \%$ when cells were treated with PM at concentration of $400 \mu \mathrm{g} / \mathrm{ml}$ (Fig. 2f). The effect of PM $\Delta \mathrm{C}$ (Fig. 2g) was less definite. These data imply that both $\mathrm{PM}$ and $\mathrm{PM} \Delta \mathrm{C}$ are cytotoxic for macrophages when used at concentrations above $100 \mu \mathrm{g} / \mathrm{ml}$. It is in agreement with other reports [21].

\section{Direct impact of PM and PM $\Delta C$ on macrophage secretory functions}

To evaluate the immunostimulatory effect of particulate matter on functioning of the inflammatory cells, supernatants were collected after $24 \mathrm{~h}$ incubation of peritoneal macrophages with increasing concentrations of PM or $\mathrm{PM} \Delta \mathrm{C}$. For the original PM samples, a dose-dependent enhancement of synthesis of all the tested cytokines (TNF$\alpha$, IL-6, IL-12p40 and IL-10) was observed (Fig. 3). The most potent effect was found at concentrations 100-200 $\mu \mathrm{g} /$ $\mathrm{ml}$. Importantly, the similar enhancement of synthesis of major proinflammatory (TNF- $\alpha$ ) and anti-inflammatory (IL10) cytokines was achieved. On the contrary, macrophages stimulated with $\mathrm{PM} \Delta \mathrm{C}$, used at the same concentrations, did not secrete any of the tested cytokines. These data suggest that PM with lowered content of organic components 
Fig. 3 Production of inflammatory mediators from mouse peritoneal macrophages after in vitro stimulation with PM and $\mathrm{PM} \Delta \mathrm{C}$. Cells were stimulated with different concentrations of either PM or PM $\Delta \mathrm{C}$. Supernatants were collected after $24 \mathrm{~h}$ and the concentrations of TNF- $\alpha$ (a), IL-6 (b) IL-12p 40 (c) and IL-10 (d), were determined as described in methods. Data are mean \pm SEM value of three independent experiments run in three technical replicates. $* P<0.05$, $* * P<0.005$, *** $P<0.0001$, $\mathrm{PM} / \mathrm{PM} \Delta \mathrm{C}$-treated vs untreated macrophages
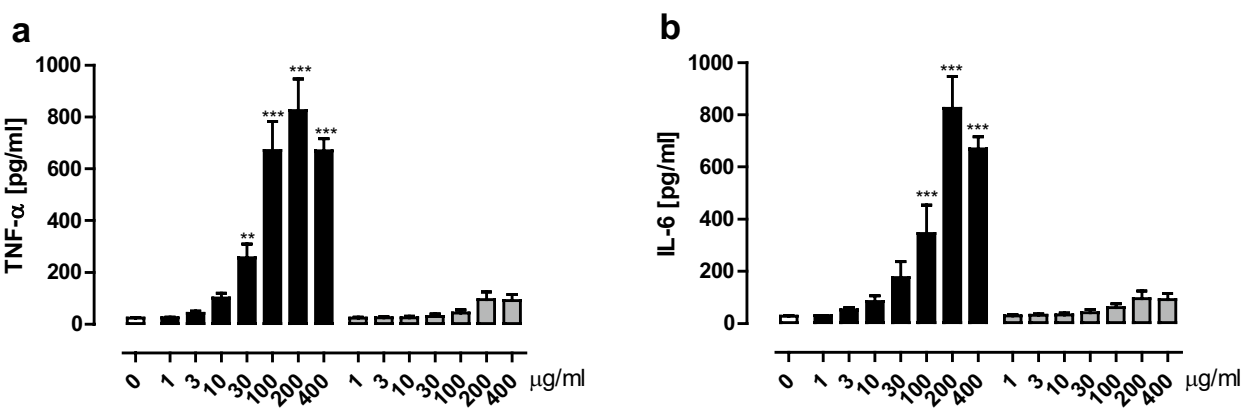

C

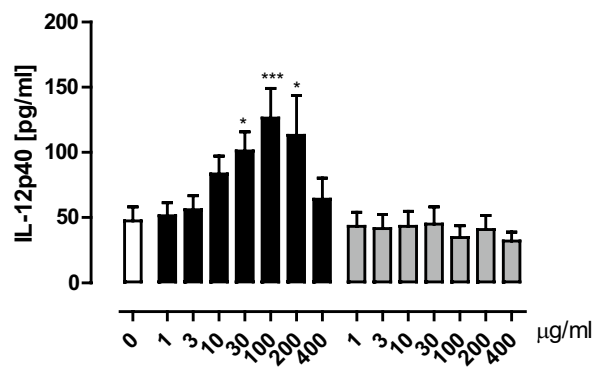

d

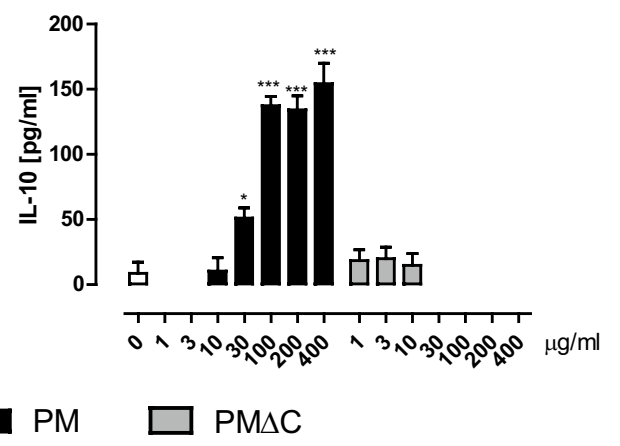

lost their ability to directly induce inflammatory response of macrophages.

\section{Priming effect of PM and PM $\triangle \mathrm{C}$ on macrophages restimulated with LPS}

To determine the impact of PM and PM $\Delta \mathrm{C}$ on macrophage state of activation, the cells were pre-incubated (primed) with various concentrations of either PM or PM $\Delta \mathrm{C}$ and then activated with LPS which induces M1-like pattern of proinflammatory mediators [18].

In this experimental setting, we observed significantly reduced production of cytokines (IL-6, IL-12p40, IL-10) by macrophages primed with high concentrations of PM and $\mathrm{PM} \Delta \mathrm{C}(>100 \mu \mathrm{g} / \mathrm{ml})$. The decrease of TNF- $\alpha$ secretion was not statistically significant (Fig. 4). By contrast, PM used at low concentrations $(10-100 \mu \mathrm{g} / \mathrm{ml})$ was able to enhance the secretion of cytokines by macrophages restimulated with LPS (Fig. 4). Most importantly, TNF- $\alpha$ secretion was significantly increased upon priming with $10-100 \mu \mathrm{g} /$ $\mathrm{ml}$ for PM and $100 \mu \mathrm{g} / \mathrm{ml}$ for PM $\Delta$ C. Concurrently, both PM and $\mathrm{PM} \Delta \mathrm{C}$ gradually decreased the production of IL-10. In addition, to evaluate the proinflammatory state of activation of primed macrophages, we have created the inflammatory cytokine ratio (ICR, Fig. 5). ICR, calculated as a ratio of TNF- $\alpha$ to IL-10 concentration, increased from ca. 9 in control group (macrophages stimulated with LPS) to above 40 in macrophages primed with both PM and PM $\Delta \mathrm{C}$ and restimulated with LPS.
We also evaluated the generation of $\mathrm{PGE}_{2}$, the major eicosanoid produced by macrophages at a site of inflammation, and the release of NO, the key microbicidal agent of activated macrophages [22-24]. The concentrations of $\mathrm{PGE}_{2}$ and $\mathrm{NO}$ were elevated in macrophages primed with PM (10-100 $\mu \mathrm{g} / \mathrm{ml}$ ) but not with PM $\Delta \mathrm{C}$ (Figs. 6c, 7b). Interestingly, NO secretion reached its peak at $10 \mu \mathrm{g} / \mathrm{ml}$ of PM with very low levels in case of higher PM concentrations.

Importantly, the production of $\mathrm{PGE}_{2}$ and $\mathrm{NO}$ did not correlate with the level of enzymes responsible for their production. The expression of COX-2 and iNOS in macrophages primed with PM/PM $\Delta \mathrm{C}$ and challenged with LPS was similar with that detected in macrophages stimulated only with LPS, while PM/PM $\Delta \mathrm{C}$ trained macrophages showed the altered production of $\mathrm{PGE}_{2} / \mathrm{NO}$ (Figs. 6a, b, 7a).

\section{Discussion}

Exposure to the air particulate matter is epidemiologically associated with various chronic inflammatory and autoimmune diseases. Notably, increased incidence and exacerbation of cardiopulmonary disorders has been found to associated with elevated levels of urban particulate matter [6, 25, 26]. Respirable particles reach the lower respiratory tract where they are phagocytosed by alveolar macrophages leading to a local inflammation [14]. The main current hypothesis is that the particles produce pulmonary inflammation with systemic release of macrophage-driven cytokines, which may influence remote cardiovascular and central 


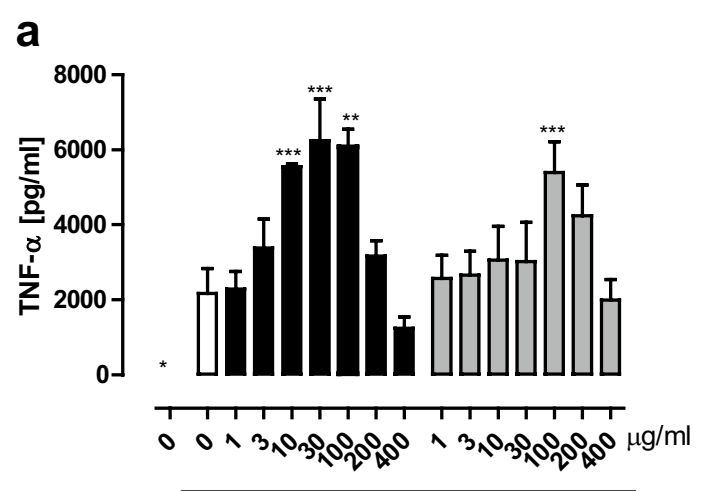

LPS $100 \mathrm{ng} / \mathrm{ml}$

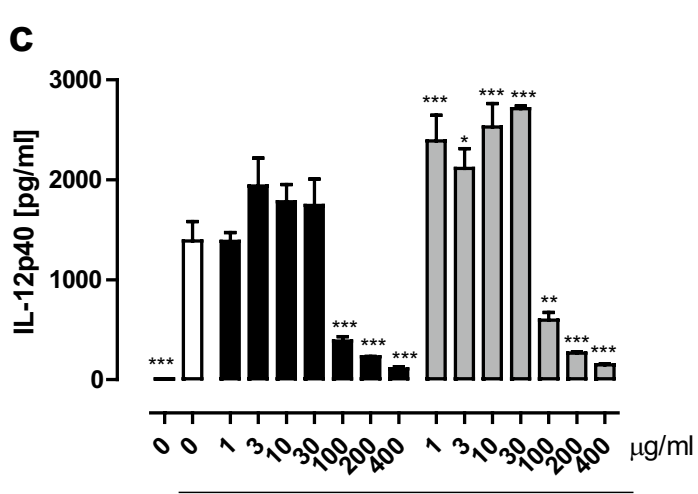

LPS $100 \mathrm{ng} / \mathrm{ml}$ b

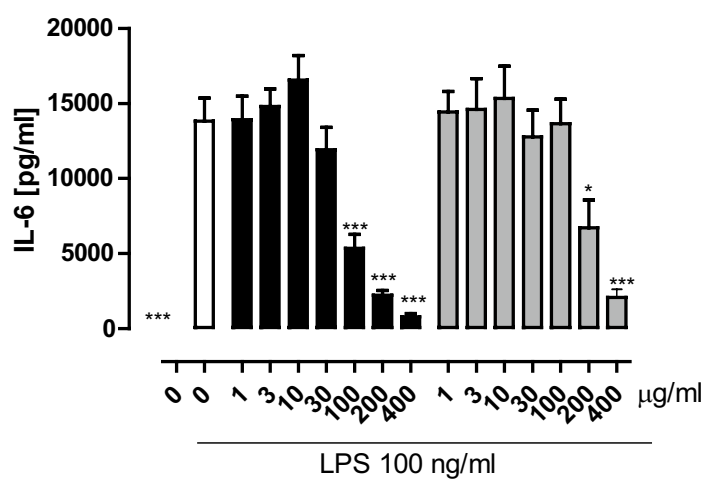

d

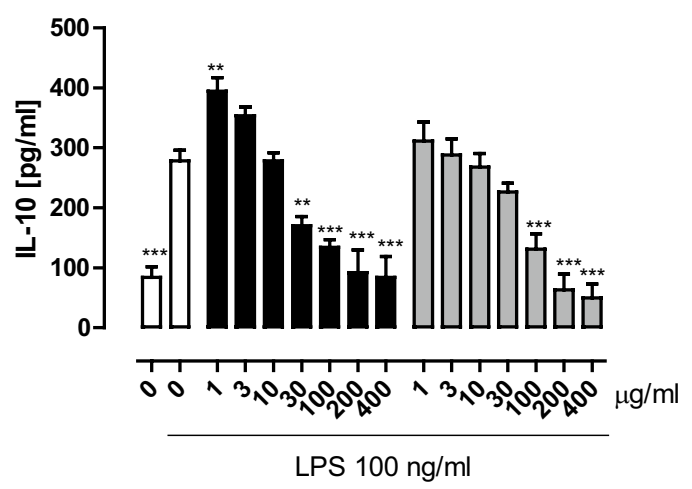

$\mathrm{PM}+\mathrm{LPS}$

\section{$\mathrm{PM} \triangle \mathrm{C}+\mathrm{LPS}$}

Fig. 4 Priming effect of $\mathrm{PM}$ and $\mathrm{PM} \Delta \mathrm{C}$ on cytokine secretion: TNF- $\alpha$ (a), IL-6 (b), IL-12p40 (c), IL-10 (d) by peritoneal macrophages. Cells $\left(5 \times 10^{5}\right.$ per well) were pre-incubated with PM samples for $24 \mathrm{~h}$ (at indicated concentrations from 1 to $400 \mu \mathrm{g} / \mathrm{ml}$ ) and then stimulated with LPS $(100 \mathrm{ng} / \mathrm{ml})$ for another $24 \mathrm{~h}$. After that time, supernatants were collected and the concentrations of cytokines were estimated by ELISA. Data are mean \pm SEM value of three

nervous system endpoints [27-29]. Nevertheless, there are conflicting and inconsistent data in the literature proving the opposing effects of various PM samples on the inflammatory response of macrophages. Numerous reports of studies on macrophages exposed to a wide spectrum of particulate matter coming from ambient air pollution provides examples of enhanced proinflammatory activity of macrophages, increased apoptosis and necrosis as well as autophagy levels [21, 30, 31]. Moreover, various mechanisms have been proposed to explain the exacerbating effect of particulate matter on the inflammatory response. First, the generation of reactive oxygen and nitrogen species might lead to development/ exacerbation of inflammatory response via oxidative/nitrosative stress induction. This effect might be enhanced by the presence of transition metals (mostly as oxides) triggering the Fenton's reaction and generation of ROS [32]. Second, it independent experiments run in three technical replicates. Control group-stationary macrophages stimulated with LPS only after $24 \mathrm{~h}$ culture in a standard medium. $* P<0.05, * * P<0.01$, $* * * P<0.001$ control macrophages (stimulated with LPS) vs macrophages primed with indicated concentrations of PM and then stimulated with LPS $100 \mathrm{ng} / \mathrm{ml}$

seems possible that proinflammatory properties of particulate matter might be attributed to the LPS contamination of the samples, as described in some reports [33]. On the other hand, there are also data on anti-inflammatory action of PM leading to suppression of the proinflammatory macrophage phenotype [14, 34]. In addition, the particulate matter has been shown to induce polarization of macrophages towards opposing M1 and M2 phenotypes [35, 36].

What would be the underlying cause of such conflicting, discrepant effects described in the literature? It is plausible that the composition of the PM samples used in different studies may vary significantly leading to various effects in the experimental models employed [14, 37]. Indeed, air pollution particulate matter is a conglomeration of many components (metals, sulfate, nitrates, hydrocarbons and endotoxin) showing distinct biological activities. Therefore, 


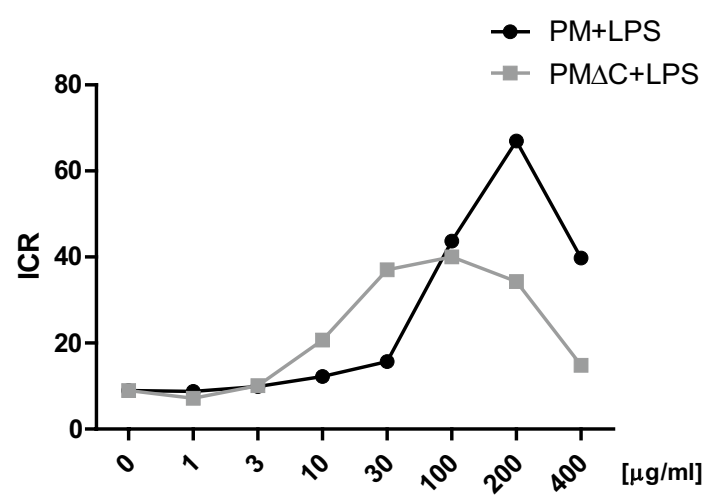

Fig. 5 Inflammatory cytokine ratio of macrophages upon $\mathrm{PM} / \mathrm{PM} \Delta \mathrm{C}$ treatment with subsequent LPS stimulation. Macrophages were preincubated with PM samples for $24 \mathrm{~h}$ (at concentrations ranging from 1 to $400 \mu \mathrm{g} / \mathrm{ml})$ and then stimulated with LPS $(100 \mathrm{ng} / \mathrm{ml})$ for another $24 \mathrm{~h}$. Inflammatory ratio is defined as TNF- $\alpha / \mathrm{IL}-10$ concentrations ratio in supernatants collected after the experiment. Data was derived from three independent experiments run in three technical replicates

either application of advanced chemical analysis of particulate matter samples seems necessary prior to cellular/animal studies to allow subsequent comparisons of the results from different research groups or standard reference material of particulate matter should be used. To address the above suggestions, in the present study we used the standard reference urban air PM (SRM 1648a) to test its influence on inflammatory response. To examine a direct and a priming effect of PM on secretory properties of murine peritoneal macrophages, two experimental models have been used, as described in the methods. Importantly, two forms of the SRM 1648a particles were studied to estimate the impact of organic compounds on their activities. Namely, intact original PM (the conglomerate of both organic and inorganic compounds) and PM deprived of carbon compounds ( $\mathrm{PM} \Delta \mathrm{C}$, containing mainly inorganic, e.g., transition-series metals compounds) were examined at concentrations of $1-400 \mu \mathrm{g} / \mathrm{ml}$. Such wide-range concentrations of PM provides low (non-active), moderate (stimulatory), as well as high (cytotoxic) amounts of the tested compounds.

In concordance with other studies [21,38], our data have shown the toxic effect of SRM 1648a (PM and PM $\Delta \mathrm{C}$ ) used at concentrations above $100 \mu \mathrm{g} / \mathrm{ml}$ (equivalent of $\sim 60 \mu \mathrm{g}$ / $\mathrm{cm}^{2}$ ). Microscopic evaluation revealed the reduced cell count and altered macrophage morphology as compared with the control (see the "Results" section). Moreover, cytometric analysis confirmed that both cell size and morphology changed in PM-treated cells. All the effects mentioned above were less pronounced in the case of $\operatorname{PM} \Delta \mathrm{C}$ which points to the importance of the organic fraction of the air pollution components for the cytotoxic effect. This observation is inconsistent with the hypothesis that mostly inorganic compounds such as transition-metal oxides (ferric, manganese oxides, etc.) are responsible for the particulate matter cytotoxicity [39]. However, the observed phenomenon might be limited to the SRM particles as we could not observe ROS generation in our experimental set-up (data not shown). On the other hand, we have observed massive release of cytokines.

Indeed, significant increase of all tested cytokines levels-both proinflammatory TNF- $\alpha$, IL-6, IL-12p40 and anti-inflammatory IL-10-was observed upon incubation of macrophages with high concentrations $(100-400 \mu \mathrm{g} / \mathrm{ml})$ of the original PM samples. It indicates that macrophages exposed to cytotoxic concentrations of PM are able to produce cytokines before they die. It may be explained by a distinct rate of cytokine production and PM-caused cell death (e.g., very fast production of TNF- $\alpha$ vs cell death via necrosis or apoptosis) [40]. In addition, dying cells might release damage-associated molecular patterns (DAMPs) that could then trigger neighboring, still alive macrophages, to produce the inflammatory mediators [41]. However, the exposure of macrophages to $\mathrm{PM} \Delta \mathrm{C}$ negates the latter mechanism, as even cytotoxic concentrations of $\mathrm{PM} \Delta \mathrm{C}$ did not evoke the production of any tested cytokine. Therefore, further studies are necessary to address the issue why PM deprived of carbon compounds loses its immunostimulatory properties.

In the next stage of our studies, we examined the priming properties of the SRM 1648a particles. It seems plausible that the effects of particulate matter might not rely on the direct impact of PM components on the cells governing the inflammation. Therefore, our studies were aimed at the evaluation of how the macrophage response to proinflammatory stimulus such as LPS might be affected if the cells were pre-exposed to particulate matter. Interestingly, we observed that the priming with original PM (at 10, 30 and $100 \mu \mathrm{g} / \mathrm{ml}$ ) induced significantly increased secretion of TNF- $\alpha$ upon subsequent LPS stimulation. Moreover, the analysis of the ratio of TNF- $\alpha$ to IL-10 levels (inflammatory cytokine ratio) revealed that higher concentrations of both $\mathrm{PM}$ and $\mathrm{PM} \Delta \mathrm{C}$ correlated with the increase of proportion of the pro- to anti-inflammatory cytokine concentrations. The studied inflammatory cytokine ratio increased with the rising concentrations of both PM and PM $\Delta \mathrm{C}$ up to $100 \mu \mathrm{g} /$ $\mathrm{ml}$. On the other hand, ICR decrease at the higher concentrations is most probably the effect of the reduced cell viability upon incubation with such high doses of particulate matter. Despite similar ICR of macrophages primed with both $\mathrm{PM}$ and $\mathrm{PM} \Delta \mathrm{C}$, some differences in the pattern of secreted mediators were observed. Namely, macrophages primed with PM exhibit enhanced secretion of TNF- $\alpha$, while IL12 p40 levels were found significantly increased when cells were pre-treated with $\mathrm{PM} \Delta \mathrm{C}$.

Interestingly, the enhancement of $\mathrm{PGE}_{2}$ and $\mathrm{NO}$ production did not correlate with the levels of enzymes responsible for their production. The expression of COX-2 and iNOS in 
a

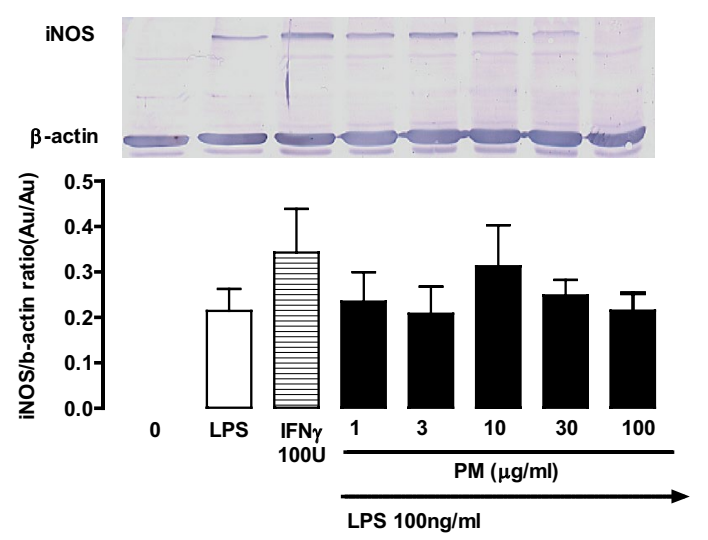

b

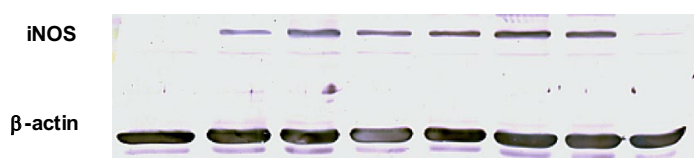

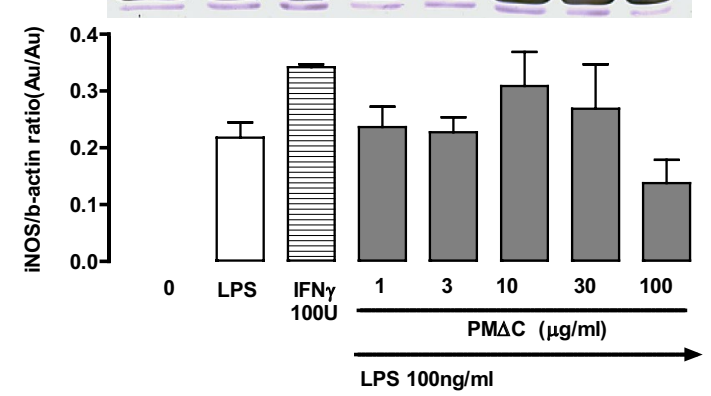

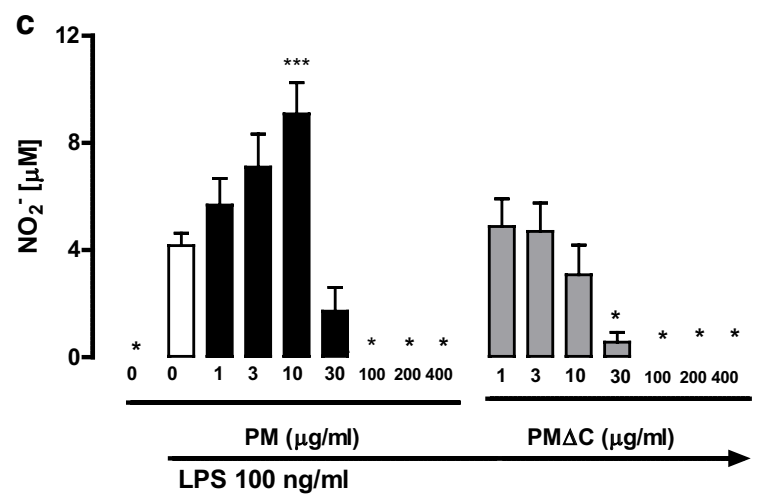

Fig. 6 Influence of PM and $\mathrm{PM} \Delta \mathrm{C}$ on the expression of iNOS and the production of nitrites by peritoneal macrophages cultured in vitro. The expression of iNOS by cells $\left(5 \times 10^{5}\right.$ per well $)$ cultured in vitro for $24 \mathrm{~h}$ in the presence of PM (a) or PM $\Delta \mathrm{C}$ (b) at indicated concentrations $(1-100 \mu \mathrm{g} / \mathrm{ml})$ is shown and then stimulated with LPS $(0.1 \mu \mathrm{g} / \mathrm{ml})$ for another $24 \mathrm{~h}$. IFN- $\gamma$ was used a positive control for iNOS production in macrophages. Representative blot picture is shown as well as the quantitative Western blot data derived from three independent experiments, normalized to constitutively expressed $\beta$-actin protein \pm SEM (no statistically significant changes were observed). The concentration of nitrites $\left(\mathrm{NO}_{2}^{-}\right)$into the culture supernatant (c) upon LPS stimulation (for $24 \mathrm{~h}$ ) of cells pre-treated with $\mathrm{PM}$ or $\mathrm{PM} \triangle \mathrm{C}$ (for $24 \mathrm{~h}$ ) was measured by Griess method. $* P<0.05, * * * P<0.001$ control macrophages (stimulated with LPS) vs macrophages primed with indicated concentrations of PM and then stimulated with LPS $0.1 \mu \mathrm{g} / \mathrm{ml}$. Data are mean values \pm SEM from three independent experiments run in three technical replicates macrophages primed with $\mathrm{PM} / \mathrm{PM} \Delta \mathrm{C}$ and challenged with LPS was similar with that detected in macrophages stimulated only with LPS. This might point to different mechanisms of regulation of $\mathrm{PGE}_{2} / \mathrm{NO}$ production in non-trained and PM-trained (primed) macrophages. The increase in PGE2 production without significant changes in the COX-2 expression suggests that macrophages pre-treated with PM and then stimulated with LPS selectively produce $\mathrm{PGE}_{2}$ with a concomitant limited production of other COX-2 products (TXA2, PGD2, PGI2, PGF2 $\alpha$ ). The differential regulation of PGE2, PGD2 and TXA2 (thromboxane A2) production in macrophages has been demonstrated [42, 43]. However, to confirm such regulation in our experimental system the concentration of mPGES-1, the specific PGE2 synthase, should be determined in further studies [44].

On the other hand, the altered production of NO without changes of iNOS expression may be explained by the regulatory properties of PGE2. It has been shown that low concentrations of PGE2 stimulate while high concentrations inhibit the production of nitric oxide [45]. Moreover, in this experimental model, we inferred about NO production from the concentration of nitrites $\left(\mathrm{NO}_{2}{ }^{-}\right)$. Therefore, without more advanced analytic studies, it is impossible to exclude the presence of other $\mathrm{NO} / \mathrm{NO}_{2}{ }^{-}$breakdown intermediates resulting from formation of end products other than the nitrites [46].

All these results suggest that exposure to PM/PM $\Delta \mathrm{C}$ could prime the macrophages for further hyperinflammatory response to other stimuli such as bacterial TLR ligands (e.g., LPS, the ligand for TLR4). Such phenomenon characterized by macrophage priming with one agent and an increased cytokine production upon restimulation with the other, is termed "trained immunity" [47, 48]. 

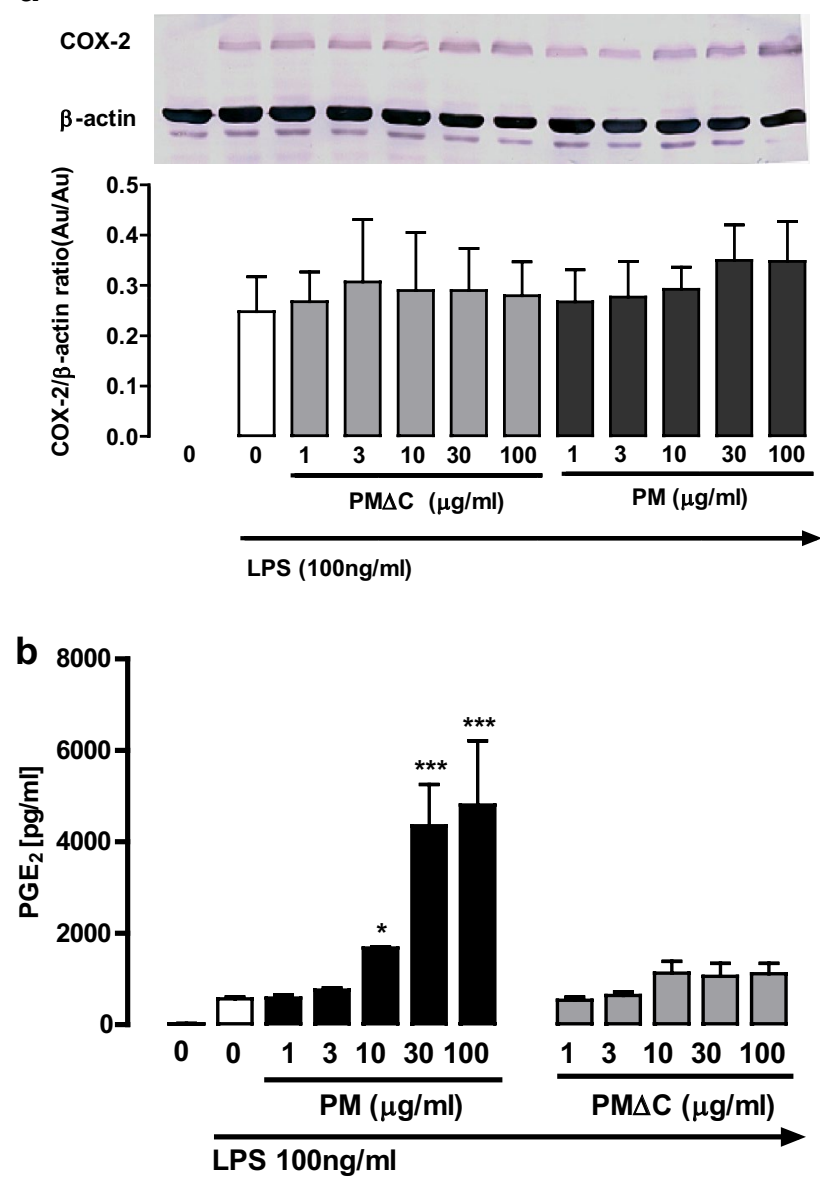

Fig. 7 Influence of $\mathrm{PM}$ and $\mathrm{PM} \Delta \mathrm{C}$ on the COX-2 expression and production of $\mathrm{PGE}_{2}$ by peritoneal macrophages cultured in vitro. The expression of COX-2 (a) and release of $\mathrm{PGE}_{2}$ into the culture supernatant (b) by cells $\left(5 \times 10^{5}\right.$ per well) cultured in vitro for $24 \mathrm{~h}$ in the presence of $\mathrm{PM}$ or $\mathrm{PM} \Delta \mathrm{C}$ at indicated concentrations $(1-100 \mu \mathrm{g} / \mathrm{ml})$ and then stimulated with LPS $(0.1 \mu \mathrm{g} / \mathrm{ml})$ for another $24 \mathrm{~h}$. Representative blot picture is shown as well as the quantitative Western blot data derived from three independent experiments, normalized to constitutively expressed $\beta$-actin protein \pm SEM (no statistically significant changes were observed). The release of PGE2 into the culture supernatant (b) upon LPS stimulation (for $24 \mathrm{~h}$ ) of cells pre-treated with PM or PM $\Delta \mathrm{C}$ (for $24 \mathrm{~h}$ ) was measured using ELISA. $* P<0.05$, $* * * P<0.001$ control macrophages (stimulated with LPS) vs macrophages primed with indicated concentrations of PM and then stimulated with LPS $100 \mathrm{ng} / \mathrm{ml}$. Data are mean values \pm SEM from three independent experiments run in three technical replicates

Importantly, the presence of organic compounds seems to be important in macrophage training with airborne PM.

Taken together, our present study points to a conclusion that the direct immunostimulatory effect of PM containing both inorganic and organic fraction, is mostly associated with the presence of cytotoxic concentrations of carbon compounds. In our experimental set-up, using the reference SRM 1648a particles, such effect was observed above the PM critical concentration of $100 \mu \mathrm{g} / \mathrm{ml}$. Nevertheless, these data do not rule out a role of transition metals present in other airborne PM in the induction of oxidative stress.

On the other hand, low concentrations of PM neither affected macrophage viability nor their function, as measured by the production of inflammatory mediators. However, PM could act as a priming agent for macrophages subsequently exposed to proinflammatory stimulus. Such trained macrophages became more sensitive to LPS stimulation which results in an amplified state of activation, characteristic for the proinflammatory M-1 type macrophages (inferred from TNF- $\alpha / \mathrm{IL}-10$ ratio analysis). This effect was not restricted to the activity of organic compounds as ICR index was similar for PM and PM $\Delta \mathrm{C}$. It indicates that exposure of the immune cells to the particulate matter may be responsible for maintaining/exacerbation of chronic inflammation (high TNF- $\alpha$ levels) and for M1-Th1 type responses (low IL-10 levels). Importantly, IL-10 has been identified as a major player in the regulation of Th1 immune responses. Thus, too much IL-10 may suppress protective T cell responses, while too little IL-10 may contribute to the development/aggravation of autoimmune disorders through an excessive activation of T cells [49].

Finally, our data suggest that exposure to even low concentrations of PM containing both inorganic and organic compounds may reprogram (train) macrophages towards the cells responding in an uncontrolled hyperinflammatory reaction upon bacterial infections. Therefore, it may explain association of the increased level of ambient air PM with exacerbation of chronic inflammatory and autoimmune disorders [8]. Moreover, a demonstration of lasting activity of such trained macrophages in a long-time experiments in vivo will support the idea concerning innate immune memory [50]. Nevertheless, further ex vivo studies with human alveolar macrophages exposed to PM are necessary to prove that results from the in vitro experimental animal models are relevant for human medicine.

Acknowledgements This work was financed by the National Science Centre (Poland, Project number 2015/16/W/ST5/00005).

Open Access This article is distributed under the terms of the Creative Commons Attribution 4.0 International License (http://creativeco mmons.org/licenses/by/4.0/), which permits unrestricted use, distribution, and reproduction in any medium, provided you give appropriate credit to the original author(s) and the source, provide a link to the Creative Commons license, and indicate if changes were made.

\section{References}

1. Anaya J-M. Common mechanisms of autoimmune diseases (the autoimmune tautology). Autoimmun Rev. 2012;11(11):781-4. https://doi.org/10.1016/j.autrev.2012.02.002.

2. Ray S, Sonthalia N, Kundu S, Ganguly S. Autoimmune disorders: an overview of molecular and cellular basis in today's perspective. 
J Clin Cell Immunol. 2012;10:003. https://doi.org/10.4172/21559899.S10-003.

3. Gawda A, Majka G, Nowak B, Marcinkiewicz J. Air pollution, oxidative stress, and exacerbation of autoimmune diseases. Cent Eur J Immunol. 2017;42(3):305-12. https://doi.org/10.5114/ ceji.2017.70975.

4. Adams DD, Knight JG, Ebringer A. Autoimmune diseases: solution of the environmental, immunological and genetic components with principles for immunotherapy and transplantation. Autoimmun Rev. 2010;9(8):525-30. https://doi.org/10.1016/j. autrev.2009.12.012.

5. Costenbader KH, Gay S, Alarcón-Riquelme ME, Iaccarino L, Doria A. Genes, epigenetic regulation and environmental factors: which is the most relevant in developing autoimmune diseases? Autoimmun Rev. 2012;11(8):604-9. https://doi. org/10.1016/j. autrev.2011.10.022.

6. Liu S-K, Cai S, Chen Y, Xiao B, Chen P, Xiang X-D. The effect of pollutional haze on pulmonary function. J Thorac Dis. 2016;8(1):E41-56. https://doi.org/10.3978/j. issn.2072-1439.2016.01.18.

7. Farhat S, Silva C, Orione M, Campos L, Sallum A, Braga A. Air pollution in autoimmune rheumatic diseases: a review. Autoimmun Rev. 2011;11(1):14-21. https://doi.org/10.1016/j.autre v.2011.06.008.

8. Ritz SA. Air pollution as a potential contributor to the 'epidemic' of autoimmune disease. Med Hypotheses. 2010;74(1):110-7. https://doi.org/10.1016/j.mehy.2009.07.033.

9. Miyata R, van Eeden SF. The innate and adaptive immune response induced by alveolar macrophages exposed to ambient particulate matter. Toxicol Appl Pharmacol. 2011;257(2):20926. https://doi.org/10.1016/j.taap.2011.09.007.

10. Mosser DM, Edwards JP. Exploring the full spectrum of macrophage activation. Nat Rev Immunol. 2008;8:958. https://doi. org/10.1038/nri2448.

11. Martinez FO, Sica A, Mantovani A, Locati M. Macrophage activation and polarization. Front Biosci J Virtual Libr. 2008. https ://doi.org/10.2741/2692.

12. Bashir S, Sharma Y, Elahi A, Khan F. Macrophage polarization: the link between inflammation and related diseases. Inflamm Res. 2016;65(1):1-11. https://doi.org/10.1007/s0001 1-015-0874-1.

13. Zhao Q, Chen H, Yang T, Rui W, Liu F, Zhang F, et al. Direct effects of airborne PM2.5 exposure on macrophage polarizations. Biochimica et Biophysica Acta Gen Subj. 2016;1860(12):283543. https://doi.org/10.1016/j.bbagen.2016.03.033.

14. Sawyer K, Mundandhara S, Ghio AJ, Madden MC. The effects of ambient particulate matter on human alveolar macrophage oxidative and inflammatory responses. J Toxicol Environ Health A. 2009;73(1):41-57. https://doi.org/10.1080/15287390903248901.

15. Pozzi R, De Berardis B, Paoletti L, Guastadisegni C. Inflammatory mediators induced by coarse (PM2.5-10) and fine (PM2.5) urban air particles in RAW 264.7 cells. Toxicology. 2003;183(13):243-54. https://doi.org/10.1016/S0300-483X(02)00545-0.

16. Pajarinen J, Kouri V-P, Jämsen E, Li T-F, Mandelin J, Konttinen YT. The response of macrophages to titanium particles is determined by macrophage polarization. Acta Biomater. 2013;9(11):9229-40. https://doi.org/10.1016/j.actbi o.2013.06.027.

17. Lu J, Xie L, Liu C, Zhang Q, Sun S. PTEN/PI3k/AKT regulates macrophage polarization in emphysematous mice. Scand J Immunol. 2017;85(6):395-405. https://doi.org/10.1111/sji.12545.

18. Mantovani A, Sica A, Locati M. Macrophage polarization comes of age. Immunity. 2005;23(4):344-6. https://doi.org/10.1016/j. immuni.2005.10.001.

19. Samek L, Furman L, Mikrut M, Regiel-Futyra A, Macyk W, Stochel G, et al. Chemical composition of submicron and fine particulate matter collected in Krakow, Poland. Consequences for the APARIC project. Chemosphere. 2017;187(Supplement C):430-9. https://doi.org/10.1016/j.chemosphere.2017.08.090.

20. Ding AH, Nathan CF, Stuehr DJ. Release of reactive nitrogen intermediates and reactive oxygen intermediates from mouse peritoneal macrophages. Comparison of activating cytokines and evidence for independent production. J Immunol. 1988;141(7):2407-12.

21. Holian A, Hamilton RF, Morandi MT, Brown SD, Li L. Urban particle-induced apoptosis and phenotype shifts in human alveolar macrophages. Environ Health Perspect. 1998;106(3):127-32.

22. Nakanishi M, Rosenberg DW. Multifaceted roles of PGE2 in inflammation and cancer. Semin Immunopathol. 2013;35(2):12337. https://doi.org/10.1007/s00281-012-0342-8.

23. Marcinkiewicz E, Marcinkiewicz J, Chłopicki S. Nitric oxide-a pro-inflammatory and anti-inflammatory mediator. Centr Eur J Immunol. 2004;28(2):74-8.

24. Maniscalco M, Sofia M, Pelaia G. Nitric oxide in upper airways inflammatory diseases. Inflamm Res. 2007;56(2):58-69. https:// doi.org/10.1007/s00011-006-6111-1.

25. Brook RD, Franklin B, Cascio W, Hong Y, Howard G, Lipsett $\mathrm{M}$, et al. Air pollution cardiovascular disease. Circulation. 2004;109(21):2655-71. https://doi.org/10.1161/01.cir.00001 28587.30041.c8.

26. Pope CA, Burnett RT, Thurston GD, Thun MJ, Calle EE, Krewski $\mathrm{D}$, et al. Cardiovascular mortality and long-term exposure to particulate air pollution. Circulation. 2004;109(1):71.

27. Nemmar A, Hoet PHM, Vanquickenborne B, Dinsdale D, Thomeer M, Hoylaerts MF, et al. Passage of inhaled particles into the blood circulation in humans. Circulation. 2002;105(4):411-4. https://doi.org/10.1161/hc0402.104118.

28. Nemmar A, Hoylaerts MF, Hoet PHM, Nemery B. Possible mechanisms of the cardiovascular effects of inhaled particles: systemic translocation and prothrombotic effects. Toxicol Lett. 2004;149(1):243-53. https://doi.org/10.1016/j.toxlet.2003.12.061.

29. Campbell A, Oldham M, Becaria A, Bondy SC, Meacher D, Sioutas C, et al. Particulate matter in polluted air may increase biomarkers of inflammation in mouse brain. Neurotoxicology. 2005;26(1):133-40. https://doi.org/10.1016/j.neuro.2004.08.003.

30. Sfv E, Wc T, Suwa T, Mukae H, Terashima T, Fujii T, et al. Cytokines involved in the systemic inflammatory response induced by exposure to particulate matter air pollutants (PM10). Am J Respir Crit Care Med. 2001;164(5):826-30. https://doi. org/10.1164/ajrccm.164.5.2010160.

31. Su R, Jin X, Zhang W, Li Z, Liu X, Ren J. Particulate matter exposure induces the autophagy of macrophages via oxidative stress-mediated PI3K/AKT/mTOR pathway. Chemosphere. 2017;167(Supplement C):444-53. https://doi.org/10.1016/j.chemo sphere.2016.10.024.

32. Ghio AJ, Carraway MS, Madden MC. Composition of air pollution particles and oxidative stress in cells, tissues, and living systems. J Toxicol Environ Health Part B. 2012;15(1):1-21. https ://doi.org/10.1080/10937404.2012.632359.

33. Schins RPF, Lightbody JH, Borm PJA, Shi T, Donaldson K, Stone V. Inflammatory effects of coarse and fine particulate matter in relation to chemical and biological constituents. Toxicol Appl Pharmacol. 2004;195(1):1-11. https://doi.org/10.1016/j. taap.2003.10.002.

34. Amakawa K, Terashima T, Matsuzaki T, Matsumaru A, Sagai M, Yamaguchi K. Suppressive effects of diesel exhaust particles on cytokine release from human and murine alveolar macrophages. Exp Lung Res. 2003;29(3):149-64. https://doi.org/10.1080/01902 140303770.

35. Hiraiwa K, van Eeden SF. Contribution of lung macrophages to the inflammatory responses induced by exposure to air 
pollutants. Mediat Inflamm. 2013;2013:619523. https://doi. org/10.1155/2013/619523.

36. He M, Ichinose T, Kobayashi M, Arashidani K, Yoshida S, Nishikawa M, et al. Differences in allergic inflammatory responses between urban PM2.5 and fine particle derived from desert-dust in murine lungs. Toxicol Appl Pharmacol. 2016;297(Supplement C):41-55. https://doi.org/10.1016/j.taap.2016.02.017.

37. Fujii T, Hayashi S, Hogg JC, Mukae H, Suwa T, Goto Y, et al. Interaction of alveolar macrophages and airway epithelial cells following exposure to particulate matter produces mediators that stimulate the bone marrow. Am J Respir Cell Mol Biol. 2002;27(1):34-41. https://doi.org/10.1165/ajrcmb.27.1.4787.

38. Obot CJ, Morandi MT, Beebe TP, Hamilton RF, Holian A. Surface components of airborne particulate matter induce macrophage apoptosis through scavenger receptors. Toxicol Appl Pharmacol. 2002;184(2):98-106. https://doi.org/10.1006/taap.2002.9493.

39. Quay JL, Reed W, Samet J, Devlin RB. Air pollution particles induce il-6 gene expression in human airway epithelial cells via NF-kb activation. Am J Respir Cell Mol Biol. 1998;19(1):98-106. https://doi.org/10.1165/ajrcmb.19.1.3132.

40. Kum WWS, Cameron SB, Hung RWY, Kalyan S, Chow AW. Temporal sequence and kinetics of proinflammatory and antiinflammatory cytokine secretion induced by toxic shock syndrome toxin 1 in human peripheral blood mononuclear cells. Infect Immun. 2001;69(12):7544-9. https://doi.org/10.1128/ iai.69.12.7544-7549.2001.

41. Vénéreau E, Ceriotti C, Bianchi ME. DAMPs from cell death to new life. Front Immunol. 2015;6:422. https://doi.org/10.3389/ fimmu.2015.00422.

42. Penglis PS, Cleland LG, Demasi M, Caughey GE, James MJ. Differential regulation of prostaglandin $\mathrm{E}_{2}$ and thromboxane $\mathrm{A}_{2}$ production in human monocytes: implications for the use of cyclooxygenase inhibitors. J Immunol. 2000;165(3):1605-11. https://doi.org/10.4049/jimmunol.165.3.1605.
43. Fournier T, Fadok V, Henson PM. Tumor necrosis factor- $\alpha$ inversely regulates prostaglandin $\mathrm{D} 2$ and prostaglandin $\mathrm{E} 2$ production in murine macrophages: synergistic action of cyclic AMP on cyclooxygenase-2 expression and prostaglandin E2 synthesis. J Biol Chem. 1997;272(49):31065-72. https://doi.org/10.1074/ jbc.272.49.31065.

44. Kudo I, Murakami M. Prostaglandin E. synthase, a terminal enzyme for prostaglandin E2 biosynthesis. J Biochem Mol Biol. 2005;38(6):633-8. https://doi.org/10.5483/bmbrep.2005.38.6.633.

45. Milano S, Arcoleo F, Dieli M, D'Agostino R, D'Agostino P, De Nucci G, et al. Prostaglandin E2 regulates inducible nitric oxide synthase in the murine macrophage cell line J774. Prostaglandins. 1995;49(2):105-15. https://doi.org/10.1016/0090-6980(94)00004 $-\mathrm{G}$.

46. Aktan F. iNOS-mediated nitric oxide production and its regulation. Life Sci. 2004;75(6):639-53. https://doi.org/10.1016/j. lfs.2003.10.042.

47. Ifrim DC, Quintin J, Joosten LAB, Jacobs C, Jansen T, Jacobs $\mathrm{L}$, et al. Trained immunity or tolerance: opposing functional programs induced in human monocytes after engagement of various pattern recognition receptors. Clin Vaccine Immunol. 2014;21(4):534-45. https://doi.org/10.1128/cvi.00688-13.

48. Deng H, Maitra U, Morris M, Li L. Molecular mechanism responsible for the priming of macrophage activation. J Biol Chem. 2013;288(6):3897-906. https://doi.org/10.1074/jbc.M112.424390.

49. Leech JM, Lacey KA, Mulcahy ME, Medina E, McLoughlin RM. IL-10 plays opposing roles during Staphylococcus aureus systemic and localized infections. J Immunol. 2017;198(6):2352-65. https://doi.org/10.4049/jimmunol.1601018.

50. Netea Mihai G, Quintin J, van der Meer Jos WM. Trained immunity: a memory for innate host defense. Cell Host Microbe. 2011;9(5):355-61. https://doi.org/10.1016/j.chom.2011.04.006. 